\title{
Role of process variable in organizational development
}

\author{
Anjan Thakur ${ }^{1}$ and Munindra Kakati ${ }^{2}$ \\ ${ }^{1}$ Research Scholar, Department of Business Administration, Gauhati University, India, \\ ${ }^{2}$ Vice Chancellor, Rajiv Gandhi University of Cooperative Management, Assam, India
}

\begin{abstract}
No study has been reported so far on the linkages between process variable and outcome variable of OD programs. This study attempts to establish the relationship between a set of process variables with the outcome variables based on in-depth study of 34 OD programs of 15 organizations. The study was conducted in 3 stages. Based on the initial assessment and literature review the study considered 76 process variables and 23 outcome variables and established their relationship through step-wise regressions.
\end{abstract}

The result of the study indicates that the clarity of vision \& mission and relationship with stakeholders are the most important process variables influencing as many as 5 outcome variables. 34 variables appear to be strong driver of OD outcomes. 29 process variables are not found to be significant influencer of outcomes and 13 process variables seem to have adverse impact on the OD outcome. Results of the study will provide beneficial insight into how OD program and process variables affect the desired outcome and accordingly OD team may set priority while designing any OD programs.

Keywords: Process variable, outcome variable, $O D$ program, OD intervention

\section{Introduction}

Organizational development is a process through which the internal capacity of an organization is improved by strengthening the process variables in order to achieve the desired output. In research terminology OD program may be called cause or enactment/ treatment that contains some independent variables (process variable) having impact on dependent variables of interest (intended outcome). However, OD itself is an independent variable causing changes in some of the process variables directly or indirectly.

Numerous studies have been conducted on identification of process and output variable, but, variable's specific role is not well understood or well researched till date. Though a few study indicates the impact of OD program on organizational effectiveness, no specific study in the Indian context has been reported so far to identify specific process variable having significant contribution to the specific outcome of an OD program. Establishing linkage between changes in process variables because of OD initiative and their impact on intended outcome is essential for practicing manager to focus on these process variables which are critical for achievement of outcome variables.

This research aims to provide:

- The linkage between process variables and outcome variables.

- Identify a set of process variables for an intended outcome.

\section{Review of Literature}

There are a few literatures which provides an excellent survey of OD research and practices covering a wide range of OD programs conducted across countries over several decades. Porras \& Berg $^{[1]}$ reviewed a set of 35 studies and found 308 different variables consisting of both process \& output variable and that overall $46 \%$ of the process variable shows positive changes. Margulies etal. ${ }^{[2]}$ analyzed 30 studies and found positive result in over $70 \%$ of them. Dunn and Swierczek ${ }^{[3]}$ examined 67 cases and found positive gains in almost $70 \%$ of the time. Various studies also found impact of OD on cost, profits and quantity and quality of products (John Nicholas ${ }^{[4]}$ ), improved productivity (Katzell and Guzzo ${ }^{[5]}$ ), performance and workers' satisfaction (Barry Macy ${ }^{[6]}$ ), worker 
productivity (Guzzo, Jette and Katzell ${ }^{[7]}$ ), attitude change (Nueman, Edwards and Raju ${ }^{[8]}$ ), increased autonomy and participation (Paul Spector ${ }^{[9]}$ ), productivity \& quality of work life (Pasmore, Francis, Haldeman and Shani ${ }^{[10]}$ ). Some of the studies also found both positive and negative effects of OD on output variable. T. M. Egan [11] was the first to specifically examine OD outcome through exploration of published definitions from the year $1969-2001$. However, none of the study explore the relationship between process variables and outcome variables which this study attempt to do so by examining 34 OD programs of 15 organizations.

\section{Materials and Methods}

The present study is based on in-depth research of 34 OD programs initiated by 15 organizations. The study was carried out in 3 stages. In the 1st stage, the researcher had interacted with the OD team members of the organizations to identify the specific (i) OD initiative taken (ii) the process variables and the intended outcomes.

There were more than 308 process and outcome variables identified by Porras \& Berg based upon 35 number of studies. All the 308 variables may not be applicable to a particular OD program. Hence, this exercise helped us to identify process and outcome variables which are relevant for $34 \mathrm{OD}$ programs under consideration. Based on the findings of the 1st stage, we have sorted out 76 process variables and 23 outcome variables.

In the 2nd stage, we prepared two sets of questionnaires, one for process variable and the other for outcome variable. The opinion of the team members of the particular OD program and their perception of changes in the process variable and also the outcome variable due to the particular OD initiative were captured using 5-point Likert scale.

While interacting with the team members, they were asked to respond to all the process variables identified and the intended outcomes as well as incidental outcomes. We used step-wise regression model to establish the linkage between the process and outcome variable under consideration and also a set of variables affecting a particular outcome. The analysis of data enabled us to develop 23 models, one corresponding to each outcome variable.

In the 3rd stage, the result of the regression model was discussed with the respective OD teams to validate the outcome and most importantly the reasons underlying the relationship.

\section{Results and Discussion}

The result of the study has been summarized in the appendix. All the 23 models are found to be effective as reflected high value of $F$ and significant level varies from 0.018 to 0.000 . R2 of the regression model varies from $24.7 \%$ to $76 \%$. As we have used step-wise regression, appendix shows only those independent variables which are significant. The independent variables shown in the table represent the order in which it entered in the step-wise regression i.e. the 1 st variable entered in the 1 st step and the 2 nd variable entered in the 2 nd step and so on. Since the number of process variables are high step-wise regression was done to eliminate the insignificant variables.

From the study it has been found that when organizational image and market standing is the desired outcome of the OD program, clarity of vision and mission at all levels followed by reward and recognition for achievement of the outcome play a crucial role. (Model 1)

Productivity appears to have strong linkage with review of performance appraisal and feedback mechanism and on existing source of revenue. It may be because of the need of creative effort of skilled manpower towards increased production at reduced cost. However, flexibility appears to be a negative driver of productivity if it is not exploited for organizational advantage by restructuring managerial and organizational process. (Model 2)

For an intended outcome of gross revenue generation, the OD program with strong inclination to revenue generation/ income generation strategy (cost saving, revenue enhancement) and market information system produce significant result. However, contrary to our belief of Board's intervention/ assessment appears to be counterproductive (Model 3)

As per the outcome of our regression model, professional accounting, IT infrastructure and successful adoption of new technology have significant influence on generation of demand for product and services. Recruitment and selection process of field staff appears to have negative impact. (Model 4) 
Effectiveness \& efficiency of manpower appears to be driven by functional flexibility in-built into the system and commitment of financial resources to achieve the desired vision \& mission; however, performance budgeting and adequacy \& suitability of tools \& equipment already in use is having negative impact. (Model 5)

If the intention of the OD initiative is to increase the effectiveness of equipment, emphasis on flexible structure system \& process as well as contingency plan to handle leadership change are of paramount importance. But policy governing the board may not be relevant for the intended outcome. Flexible structure system \& process and adoption of new technology may be considered as primary requirement for implementation of TPM aiming at increased production uptime. Flexibility of structure, system and process refers to flexibility in process, flexibility to accept different feed quality and flexibility in product yield. All of these contributes to production uptime. But, time-worthy decision making may not yield the desired outcome. (Model 6)

Functional flexibility and adequacy of space are the major driver for energy saving because functional flexibility enables use of alternative energy which is also cost effective. For e.g. two types of fuel are used in boilers and furnace i.e. fuel oil \& gas. The fuel oil is costlier than gas. When fuel gas used instead of fuel oil it leads to saving of costly energy. Moreover, most energy saving activities take place by exchanging heat through heat exchangers. Erection of heat exchangers require sizable space. Hence, adequacy of space has bearing upon energy saving. But, the emphasis on reward \& recognition may not yield any desirable outcome with respect to energy saving. (Model 7)

Information when properly processed become knowledge. Knowledge is a requirement for creativity which is a path to innovation. Any OD intervention for innovation must develop a system for information processing. However, clear management responsibility may not contribute significantly to innovation. (Model 8)

Any OD program aiming at proper accountability must put adequate emphasis on alignment of financial expenditure with vision $\&$ mission, which enables proper monitoring and control. (Model 9)

OD intervention with thrust for knowledge management must emphasize regular review of human resource management policy. Reviewed
HRM policy manuals when circulated make knowledge explicit into the system, which contributes to knowledge management in the organization. (Model 10)

The customer satisfaction is the composite result of the processes such as role clarity, productive working relationship with internal and external customer, alignment of financial expenditure with vision \& mission and sustained relationship with stakeholders. However, frequent strategic decision making and integration of top management may not have a bearing upon customer satisfaction as it appears to be. (Model 11)

The study indicates that OD program aiming at reducing absenteeism should adopt Human Resource Information System (HRIS) which creates scope for online monitoring of attendance, leave, leave application, leave approval and introduce biometric card for attendance, which minimizes manual workload and establish better monitoring and control. Besides, different measures for building interpersonal relation, grievance handling, periodic health checkup, celebration of birthday at workplace reduce attitude for absence among employees. However, system and process of information \& retrieval along with the process for conflict resolution may not yield the desired result. (Model 12)

OD program for creating scope for learning must strengthen the process of assessment \& measurement of outcome which enables analysis and accordingly adopt corrective measures. Learning appears to be more efficient, effective and faster when the audit program has in-built innovation and team members are conversant to the entire OD process. However, orientation of board members and frequent strategic decision making may not lead to the desirable learning outcome. (Model 13)

OD intervention strategy adopted by majority of the organizations reveal that clarity of vision \& mission contribute significantly for problem solving and continual improvement. The motto of TPM \& Kaizen is continuous development. Continuous improvement in workplace are done through innovative ideas generated through Kaizen, suggestion scheme, quality circles etc. (Model 14)

The study indicates that application of PDCA cycle and flexible structure system $\&$ process contributes to safe working environment. However, management information system \& database may 
not contribute the desired objective. For e.g. Planning of job is done in consultation with both the maintenance and operation personnel in zonal meetings at early hours of the day. Preparation of job site is done to make it safe for doing job. The permission of doing job are given by operational group leader through online SAP system. The job site safety aspects are to be reviewed in 4 hours' interval which leads to safe working environment. In addition, flexible structure system \& process adds to safe working environment. For e.g. Flexible firefighting facilities. But, Management Information System \& Database may not contribute to the desired objectives. (Model 15)

Quality of work life can be termed as better when the employee can take satisfaction by performing the task assigned successfully. (Model 16)

Our study indicates that for any OD program intending to increase the motivation of employees must give due emphasis on assessment and measurement of performance, reward \& recognition and revenue generation strategy. As such, motivation of employees is the composite result of the process of assessment $\&$ measurement and revenue generation strategy. However, orientation of board members is not significant with respect to the desired objective. (Model 17)

Job description and determination of KRA provides clarity for performing the job for contributing towards the vision, which enables formation of coherent group with clear performance indicator. So, OD intervention for creating coherent group with clear performance indicator must put emphasis on job description and clarity of vision. (Model 18)

Proper planning and empowerment only contribute towards involvement towards participation of the group in problem solving. Our study indicates that process of empowerment of employee is a driver for group consensus. Clear management responsibility may adversely affect group consensus. (Model 19)

OD program intending to enhance strategic capability need to emphasize the process of building relationship with stakeholders, proper development of funding proposal, strategic direction of the board, defined working relationship and review of performance appraisal and feedback mechanism. However, frequent strategic decision making and consistency may have adverse impact. (Model 20)
OD intervention strategy for development of a controlled mechanism for enabled improved performance required to emphasize on designing the process of MIS, clear decision making, revenue generation and relationship with stakeholders. However, process of creating physical layout of workspace and review of staffing pattern may be counterproductive. (Model 21)

Process of sustaining the existing source of revenue and relationship with stakeholders contributes to effective leadership and organizational productivity. However, frequent restructuring and strategic direction of the board may have negative impact. (Model 22)

Participation appears to be better when better review of performance and feedback mechanism is in place and when the team is engaged in better relationship with stakeholders. However, presence of IT infrastructure appears to be ineffective in enhancing participation. (Model 23)

\section{Conclusions}

The present study intends to unearth some linkages between process variables and outcome variables which may provide beneficial insight into how OD program and process variable affect the desired outcome. Accordingly, the OD team may set priority while designing any OD program. The study indicates that:

1. Clarity of vision \& mission and relationship with the stakeholders are two very effective process variable impacting multiple outcome variables. The clarity of vision \& mission is the driver for Organizational Image \& Market Standing, Production \& Productivity, Problem Solving \& Continual Improvement, Relatively Better QWL, Coherent Group with Clear Performance Indicators for Appraisals.

Relationship with stakeholder influence Learning Environment, Strategic Capability, Control Mechanism Enabled Improved Performance, Leadership Effectiveness \& Productivity of Groups \& Individuals and Participation.

2. Many outcome variables are found to be affected by a single process variable. However, few output variables demand collective action of $n$ number of process variables for desired outcome to be achieved. In most of the OD we have investigated the incidental outcomes/ 
benefit appears to be more prominent than the intended outcomes.

3. 29 process variables did not appear in any of the 23 models. That does not mean that they are not important in the context of OD intervention. They become insignificant, may be because of the fact that all these process variables are sufficiently present in all the 34 cases under reference, or insufficiently present in all the cases.

4. The magnitude of changes in process variables as well as outcome variables can be large or small and vary widely across the OD programs.

5. Contrary to our belief, orientation of the board members and their decision appears to have adverse contribution to the OD outcome.
6. Changes in the process variables may be deliberate or incidental.

7. For different outcome the changes needed in the process variables are different, hence it is difficult to generalize a particular approach to OD intervention.

8. The investigation of the causes of absence of these process variables may require deeper study considering large samples across different category of OD initiatives. Hence, thorough analysis of both set of variables and their relationship may be the area for future research.

\section{Appendix}

Table 1: Step-wise regression model between process variable (independent) and outcome variable (dependent)

\begin{tabular}{|c|c|c|c|c|}
\hline $\begin{array}{c}\text { Model } \\
\text { No. }\end{array}$ & Outcome Variables & Value & Impacting Process Variables & Value \\
\hline \multirow[t]{2}{*}{1} & \multirow{2}{*}{$\begin{array}{l}\text { Organisational Image } \\
\& \text { Market Standing }\end{array}$} & \multirow{2}{*}{$\begin{array}{l}R=0.75, R^{2}=53 \% \\
F=25.2, \text { Sig }=0.000\end{array}$} & Clarity & $\beta=0.691, t=5.87$, sig $=0.000$ \\
\hline & & & Reward \& Recognition & $\begin{array}{c}\beta=0.346, t=2.916 \\
\text { sig }=0.007\end{array}$ \\
\hline \multirow[t]{4}{*}{2} & \multirow[t]{4}{*}{ Productivity } & \multirow{4}{*}{$\begin{aligned} \mathrm{R}=0.79, \mathrm{R}^{2} & =59 \%, \mathrm{~F}=17, \\
\text { Sig } & =0.00\end{aligned}$} & Clarity & $\beta=0.565, \mathrm{t}=3.87, \mathrm{sig}=0.000$ \\
\hline & & & Existing Source of Revenue & $\beta=0.72, t=5.1$, sig $=0.00$ \\
\hline & & & $\begin{array}{c}\text { Review of Performance Appraisal } \\
\text { \& Feedback System }\end{array}$ & $\beta=0.57, \mathrm{t}=4.7, \mathrm{sig}=0.00$ \\
\hline & & & $\begin{array}{c}\text { Machine Flexibility, Process } \\
\text { Flexibility, Product Flexibility \& } \\
\text { Routine Flexibility }\end{array}$ & $\begin{array}{c}\beta=-0.39, t=-0.26, \\
\text { sig }=0.01\end{array}$ \\
\hline \multirow[t]{3}{*}{3} & \multirow[t]{3}{*}{ Gross Revenue } & \multirow[t]{3}{*}{$\begin{array}{c}R=0.777, R^{2}=56.41 \% \\
F=15.2, \text { Sig }=0.000\end{array}$} & Revenue Generation Strategy & $\beta=0.584, t=4.67$, sig $=0.000$ \\
\hline & & & $\begin{array}{c}\text { System \& Process of Information } \\
\text { \& Retrieval }\end{array}$ & $\beta=0.344, t=2.69$, sig $=0.011$ \\
\hline & & & Strategic Direction of the Board & $\begin{array}{c}\beta=-0.248, t=-2.68, \\
\quad \text { sig }=0.044\end{array}$ \\
\hline \multirow[t]{3}{*}{4} & \multirow[t]{3}{*}{$\begin{array}{l}\text { Demand for Product } \\
\text { \& Service }\end{array}$} & \multirow[t]{3}{*}{$\begin{array}{c}\mathrm{R}=0.687, \mathrm{R}^{2}=39.9 \% \\
\mathrm{~F}=6.47, \mathrm{Sig}=0.001\end{array}$} & Professional Accounting & $\beta=0.618, t=4.1$, sig $=0.000$ \\
\hline & & & Adequate IT Infrastructure & $\beta=0.31, t=2.1$, sig $=0.037$ \\
\hline & & & Adoption of New Technology & $\beta=0.469, t=2.97$, sig $=0.006$ \\
\hline
\end{tabular}




\begin{tabular}{|c|c|c|c|c|}
\hline & & & $\begin{array}{l}\text { Objective Consistent Documented } \\
\text { Recruitment \& Selection }\end{array}$ & $\begin{array}{c}\beta=-0.37, \mathrm{t}=-2.17, \mathrm{sig}=- \\
0.4\end{array}$ \\
\hline \multirow[t]{4}{*}{5} & \multirow{4}{*}{$\begin{array}{c}\text { Effectiveness \& } \\
\text { Efficiency of } \\
\text { Manpower }\end{array}$} & \multirow[t]{4}{*}{$\begin{array}{c}\mathrm{R}=0.688, \mathrm{R}^{2}=42 \%, \\
\mathrm{~F}=8.9, \mathrm{Sig}=0.000\end{array}$} & Functional Flexibility & $\beta=0.35, \mathrm{t}=3, \mathrm{sig}=0.005$ \\
\hline & & & Performance Budgeting & $\beta=-0.7, \mathrm{t}=-3.9, \mathrm{sig}=0.000$ \\
\hline & & & $\begin{array}{c}\text { Financial Expenditure Aligned } \\
\text { with Vision \& Mission }\end{array}$ & $\beta=1.019, \mathrm{t}=5, \operatorname{sig}=0.000$ \\
\hline & & & $\begin{array}{c}\text { Adequacy \& Suitability of Tools, } \\
\text { Equipment \& Process }\end{array}$ & $\begin{array}{c}\beta=-0.48, \mathrm{t}=-2.8 \\
\operatorname{sig}=0.008\end{array}$ \\
\hline \multirow[t]{6}{*}{6} & \multirow[t]{6}{*}{$\begin{array}{l}\text { Increased Equipment } \\
\text { Effectiveness \& } \\
\text { Production Uptime }\end{array}$} & \multirow[t]{6}{*}{$\begin{array}{c}\mathrm{R}=0.78, \mathrm{R}^{2}=57.2 \% \\
\mathrm{~F}=15.2, \mathrm{Sig}=0.00\end{array}$} & $\begin{array}{l}\text { Contingency Plan to Handle } \\
\text { Leadership Change }\end{array}$ & $\beta=0.466, \mathrm{t}=3.18, \mathrm{sig}=0.003$ \\
\hline & & & Policy Governing the Board & $\beta=-0.46, t=-3, \operatorname{sig}=0.004$ \\
\hline & & & $\begin{array}{c}\text { Flexible Structure System \& } \\
\text { Process }\end{array}$ & $\beta=0.418, \mathrm{t}=2.81, \mathrm{sig}=0.009$ \\
\hline & & & Adoption of New Technology & $\beta=0.339, \mathrm{t}=2.85, \mathrm{sig}=0.008$ \\
\hline & & & $\begin{array}{c}\text { Flexible Structure System \& } \\
\text { Process }\end{array}$ & $\beta=0.81, \mathrm{t}=5.1, \mathrm{sig}=0.000$ \\
\hline & & & Time Worthy Decision Making & $\beta=-6.5, \mathrm{t}=-4.2, \mathrm{sig}=0.000$ \\
\hline \multirow[t]{3}{*}{7} & \multirow[t]{3}{*}{ Energy Saving } & \multirow[t]{3}{*}{$\begin{array}{l}\mathrm{R}=0.72, \mathrm{R}^{2}=48 \% \\
\mathrm{~F}=11.2, \mathrm{Sig}=0.000\end{array}$} & Functional Flexibility & $\beta=0.56, t=3.14$, sig $=0.004$ \\
\hline & & & Reward \& Recognition & $\begin{array}{c}\beta=-0.34, \mathrm{t}=-2.5 \\
\operatorname{sig}=0.018\end{array}$ \\
\hline & & & Adequacy of Space & $\beta=0.368, t=2.4, \operatorname{sig}=0.022$ \\
\hline \multirow[t]{2}{*}{8} & \multirow[t]{2}{*}{$\begin{array}{l}\text { Financial Benefits } \\
\text { through Innovation }\end{array}$} & \multirow[t]{2}{*}{$\begin{array}{c}\mathrm{R}=0.56, \mathrm{R}^{2}=27.1 \% \\
\mathrm{~F}=6.2, \mathrm{Sig}=0.018\end{array}$} & Clear Management Responsibility & $\beta=-0.45, \mathrm{t}=-3, \mathrm{sig}=0.005$ \\
\hline & & & $\begin{array}{c}\text { System \& Process of Information } \\
\text { \& Retrieval }\end{array}$ & $\beta=0.39, \mathrm{t}=2.62, \mathrm{sig}=0.01$ \\
\hline 9 & $\begin{array}{c}\text { Accountability \& } \\
\text { Control }\end{array}$ & $\begin{array}{c}\mathrm{R}=0.51, \mathrm{R}^{2}=24.7 \%, \\
\mathrm{~F}=11.8 \\
\mathrm{Sig}=0.002\end{array}$ & $\begin{array}{c}\text { Financial Expenditure Aligned } \\
\text { with Vision \& Mission }\end{array}$ & $\beta=0.519, \mathrm{t}=3.49, \mathrm{sig}=0.002$ \\
\hline 10 & $\begin{array}{c}\text { Knowledge } \\
\text { Management }\end{array}$ & $\begin{array}{l}\mathrm{R}=0.568, \mathrm{R}^{2}=30.2 \% \\
\mathrm{~F}=15.24, \mathrm{Sig}=0.000\end{array}$ & Regular Review of HRMP & $\beta=0.568, t=3.9$, sig $=0.000$ \\
\hline \multirow[t]{5}{*}{11} & \multirow[t]{5}{*}{ Customer Satisfaction } & \multirow[t]{5}{*}{$\begin{array}{c}\mathrm{R}=0.84, \mathrm{R}^{2}=66.5 \% \\
\mathrm{~F}=17.3, \mathrm{Sig}=0.00\end{array}$} & $\begin{array}{l}\text { Role Clarity \& Productive Working } \\
\text { Relationship }\end{array}$ & $\beta=0.66, \mathrm{t}=4.6, \mathrm{sig}=0.00$ \\
\hline & & & $\begin{array}{c}\text { Frequent Strategic Decision } \\
\text { Making }\end{array}$ & $\begin{array}{c}\beta=-0.33, \mathrm{t}=-2.3 \\
\operatorname{sig}=0.027\end{array}$ \\
\hline & & & $\begin{array}{c}\text { Financial Expenditure Aligned } \\
\text { with Vision \& Mission }\end{array}$ & $\beta=0.77, \mathrm{t}=6.48, \mathrm{sig}=0.000$ \\
\hline & & & Job Description Flexibility & $\beta=-0.5, t=-3.9$, sig $=0.000$ \\
\hline & & & Sustaining In-depth Relationship & $\beta=0.431, t=2.7$, sig $=0.01$ \\
\hline
\end{tabular}




\begin{tabular}{|c|c|c|c|c|}
\hline & & & Integrated Top Management Team & $\beta=-0.61, t=-4, \operatorname{sig}=0.000$ \\
\hline & & & Effective Conflict Resolution & $\beta=0.69, t=4.2$, sig $=0.000$ \\
\hline \multirow[t]{4}{*}{12} & \multirow[t]{4}{*}{$\begin{array}{l}\text { Reduction of } \\
\text { Absenteeism }\end{array}$} & \multirow[t]{4}{*}{$\begin{array}{c}\mathrm{R}=0.84, \mathrm{R}^{2}=66.6 \% \\
\mathrm{~F}=14.1, \mathrm{Sig}=0.00\end{array}$} & Adoption of New Technology & $\beta=0.4, t=3.2, \operatorname{sig}=0.003$ \\
\hline & & & Sustaining In-depth Relationship & $\beta=0.74, t=4.4$, sig $=0.000$ \\
\hline & & & $\begin{array}{c}\text { System \& Process of Information } \\
\& \text { Retrieval }\end{array}$ & $\beta=-0.5, t=-3.9$, sig $=0.001$ \\
\hline & & & Effective Conflict Resolution & $\beta=-0.33, t=-2.1, \operatorname{sig}=0.04$ \\
\hline \multirow[t]{8}{*}{13} & \multirow[t]{8}{*}{$\begin{array}{c}\text { Learning } \\
\text { Environment }\end{array}$} & \multirow[t]{8}{*}{$\begin{array}{l}R=0.89, R^{2}=76 \% \\
F=21.9, \text { Sig }=0.00\end{array}$} & Assessment/ Measurement & $\beta=0.625, \mathrm{t}=4.5, \mathrm{sig}=0.00$ \\
\hline & & & Relationship with Stakeholders & $\beta=0.63, t=3.7$, sig $=0.001$ \\
\hline & & & $\begin{array}{c}\text { Frequent Strategic Decision } \\
\text { Making }\end{array}$ & $\beta=-0.4, \mathrm{t}=-2.4, \mathrm{sig}=0.02$ \\
\hline & & & $\begin{array}{l}\text { HRM Policy complies with } \\
\text { Regulatory Requirement }\end{array}$ & $\beta=0.57, \mathrm{t}=4, \mathrm{sig}=0.00$ \\
\hline & & & In-built Innovation & $\beta=0.63, t=5.6$, sig $=0.00$ \\
\hline & & & Orientation of Board Members & $\begin{array}{c}\beta=-0.58, t=-4.7 \\
\text { sig }=0.000\end{array}$ \\
\hline & & & $\begin{array}{c}\text { Frequent Strategic Decision } \\
\text { Making }\end{array}$ & $\beta=-4.3, t=-3.3, \operatorname{sig}=0.001$ \\
\hline & & & Conversant & $\beta=0.35, \mathrm{t}=2.9, \mathrm{sig}=0.006$ \\
\hline 14 & $\begin{array}{l}\text { Problem Solving \& } \\
\text { Continual } \\
\text { Improvement }\end{array}$ & $\begin{array}{c}\mathrm{R}=0.627, \mathrm{R}^{2}=37.5 \%, \\
\mathrm{~F}=20.9, \mathrm{Sig}=0.00\end{array}$ & Clarity & $\beta=0.627, \mathrm{t}=4.5, \mathrm{sig}=0.00$ \\
\hline \multirow[t]{3}{*}{15} & \multirow[t]{3}{*}{$\begin{array}{l}\text { Safe Working } \\
\text { Environment }\end{array}$} & \multirow[t]{3}{*}{$\begin{array}{c}\mathrm{R}=0.74, \mathrm{R}^{2}=50.9 \% \\
\mathrm{~F}=12.4, \mathrm{Sig}=0.00\end{array}$} & $\begin{array}{c}\text { Application of PDCA for Quality } \\
\text { Standard with respect to Workflow } \\
\& \text { Workload }\end{array}$ & $\beta=0.84, \mathrm{t}=5.3, \mathrm{sig}=0.00$ \\
\hline & & & $\begin{array}{c}\text { Management Information System } \\
\& \text { Database }\end{array}$ & $\beta=-052, \mathrm{t}=-3.2, \operatorname{sig}=0.003$ \\
\hline & & & $\begin{array}{c}\text { Flexible Structure System \& } \\
\text { Process }\end{array}$ & $\beta=0.33, \mathrm{t}=2.5, \mathrm{sig}=0.018$ \\
\hline \multirow[t]{2}{*}{16} & \multirow[t]{2}{*}{$\begin{array}{c}\text { Relatively Better } \\
\text { QWL }\end{array}$} & \multirow[t]{2}{*}{$\begin{array}{c}R=0.62, R^{2}=34.5 \% \\
F=9.6, S i g=0.001\end{array}$} & $\begin{array}{c}\text { Application of PDCA for Quality } \\
\text { Standard with respect to Workflow } \\
\& \text { Workload }\end{array}$ & $\beta=0.39, \mathrm{t}=2.56, \mathrm{sig}=0.016$ \\
\hline & & & Clarity & $\beta=0.35, \mathrm{t}=2.29, \mathrm{sig}=0.028$ \\
\hline \multirow[t]{2}{*}{17} & \multirow[t]{2}{*}{$\begin{array}{l}\text { Motivation of } \\
\text { Employees }\end{array}$} & \multirow[t]{2}{*}{$\begin{array}{c}\mathrm{R}=0.83, \mathrm{R}^{2}=64.7 \% \\
\mathrm{~F}=16, \mathrm{Sig}=0.00\end{array}$} & Assessment/ Measurement & $\beta=0.52, t=3.5$, sig $=0.002$ \\
\hline & & & Orientation of Board Members & $\beta=-0.6, t=-4.3$, sig $=0.00$ \\
\hline
\end{tabular}


ISSN 2455-6378

\begin{tabular}{|c|c|c|c|c|}
\hline & & & Revenue Generation Strategy & $\beta=0.46, t=3.1$, sig $=0.003$ \\
\hline & & & Review & $\beta=0.35, t=2.76, \operatorname{sig}=0.01$ \\
\hline \multirow[t]{3}{*}{18} & \multirow{3}{*}{$\begin{array}{l}\text { Coherent Group with } \\
\text { Clear Performance } \\
\text { Indicators for } \\
\text { Appraisals }\end{array}$} & \multirow[t]{3}{*}{$\begin{array}{c}\mathrm{R}=0.66, \mathrm{R}^{2}=39 \%, \mathrm{~F}=8 \\
\text { Sig }=0.00\end{array}$} & Job Description & $\beta=0.58, \mathrm{t}=3.1, \mathrm{sig}=0.003$ \\
\hline & & & Clarity & $\beta=0.47, t=2.9$, sig $=0.007$ \\
\hline & & & Review & $\beta=-0.4, \mathrm{t}=-2.1, \mathrm{sig}=0.036$ \\
\hline \multirow[t]{2}{*}{19} & \multirow[t]{2}{*}{$\begin{array}{l}\text { Group Consensus and } \\
\text { Problem Solving }\end{array}$} & \multirow[t]{2}{*}{$\begin{array}{c}\mathrm{R}=0.66, \mathrm{R}^{2}=40.5 \% \\
\mathrm{~F}=12.2, \mathrm{Sig}=0.00\end{array}$} & Empowered Employees & $\beta=0.63, t=4.6, \operatorname{sig}=0.00$ \\
\hline & & & Clear Management Responsibility & $\beta=-0.3, \mathrm{t}=-2.2, \operatorname{sig}=0.03$ \\
\hline \multirow[t]{7}{*}{20} & \multirow[t]{7}{*}{ Strategic Capability } & \multirow[t]{7}{*}{$\begin{array}{c}\mathrm{R}=0.89, \mathrm{R}^{2}=74.9 \% \\
\mathrm{~F}=15, \mathrm{Sig}=0.00\end{array}$} & Relationship with Stakeholders & $\beta=0.56, t=4.9$ sig $=0.00$ \\
\hline & & & Development of Funding Proposal & $\beta=0.42, \mathrm{t}=4.2, \mathrm{sig}=0.00$ \\
\hline & & & Defined Working Relationship & $\beta=0.47, \mathrm{t}=3.5, \mathrm{sig}=0.002$ \\
\hline & & & $\begin{array}{c}\text { Adequacy \& Suitability of Tools, } \\
\text { Equipment \& Process }\end{array}$ & $\beta=-0.71, \mathrm{t}=-5.5, \mathrm{sig}=0.00$ \\
\hline & & & $\begin{array}{c}\text { Review of Performance Appraisal } \\
\text { \& Feedback System }\end{array}$ & $\beta=0.68, t=4.6$, sig $=0.00$ \\
\hline & & & $\begin{array}{c}\text { Frequent Strategic Decision } \\
\text { Making }\end{array}$ & $\begin{array}{c}\beta=-0.45, \mathrm{t}=-3.6 \\
\operatorname{sig}=0.001\end{array}$ \\
\hline & & & Consistency & $\beta=-0.3, \mathrm{t}=-2, \operatorname{sig}=0.06$ \\
\hline \multirow[t]{6}{*}{21} & \multirow{6}{*}{$\begin{array}{c}\text { Control Mechanism } \\
\text { Enabled Improved } \\
\text { Performance }\end{array}$} & \multirow[t]{6}{*}{$\begin{array}{c}\mathrm{R}=0.83, \mathrm{R}^{2}=63 \%, \mathrm{~F}=10, \\
\mathrm{Sig}=0.00\end{array}$} & $\begin{array}{c}\text { Management Information System } \\
\text { \& Database }\end{array}$ & $\beta=0.47, t=3.2$, sig $=0.003$ \\
\hline & & & $\begin{array}{c}\text { Proper Physical Layout of } \\
\text { Workspace }\end{array}$ & $\beta=-0.5, \mathrm{t}=4.2, \mathrm{sig}=0.000$ \\
\hline & & & Clear Decision Making Process & $\beta=0.4, t=3.8, \operatorname{sig}=0.001$ \\
\hline & & & Review of Staffing Pattern & $\beta=-0.5, \mathrm{t}=-3.4, \mathrm{sig}=0.002$ \\
\hline & & & Revenue Generation Strategy & $\beta=0.29, \mathrm{t}=2.3, \mathrm{sig}=0.02$ \\
\hline & & & Relationship with Stakeholders & $\beta=0.31, t=2, \operatorname{sig}=0.06$ \\
\hline \multirow[t]{4}{*}{22} & \multirow{4}{*}{$\begin{array}{c}\text { Leadership } \\
\text { Effectiveness \& } \\
\text { Productivity of } \\
\text { Groups \& Individuals }\end{array}$} & \multirow[t]{4}{*}{$\begin{array}{c}\mathrm{R}=0.84, \mathrm{R}^{2}=66.8 \% \\
\mathrm{~F}=17.5, \mathrm{Sig}=0.00\end{array}$} & Relationship with Stakeholders & $\beta=0.82, \mathrm{t}=6.5, \mathrm{sig}=0.00$ \\
\hline & & & Existing Source of Revenue & $\beta=0.45, \mathrm{t}=4.3, \mathrm{sig}=0.00$ \\
\hline & & & Strategic Direction of the Board & $\beta=-0.26, \mathrm{t}=-2.2, \operatorname{sig}=0.03$ \\
\hline & & & Frequent Restructuring & $\beta=-0.24, \mathrm{t}=-2.2, \operatorname{sig}=0.04$ \\
\hline \multirow[t]{2}{*}{23} & \multirow[t]{2}{*}{ Participation } & \multirow[t]{2}{*}{$\begin{array}{l}\mathrm{R}=0.75, \mathrm{R}^{2}=52 \% \\
\mathrm{~F}=13.3, \mathrm{Sig}=0.00\end{array}$} & Relationship with Stakeholders & $\beta=0.51, t=3.7$, sig $=0.001$ \\
\hline & & & Adequate IT Infrastructure & $\begin{array}{c}\beta=-0.44, t=-3.3, \\
\operatorname{sig}=0.002\end{array}$ \\
\hline
\end{tabular}




\section{Acknowledgments}

Authors of this research paper is grateful to the OD team members of various public \& private sector industries and institutions including banking and educational institution for their kind cooperation and help in the process of carrying out the research by sharing information and participation in the process of validation of result.

\section{Reference}

[1] Jerry I. Porras, P.O. Berg, "The Impact of Organization Development", Academy of Management Review Vol. 3, No. 2, April 1978

[2] Newton Margulies, Wright Pl, Richard W. Scholl, "Organisation Development Techniques; Their impact on change", group and organization studies, 2, no.4 (Dec. 1977). 449

[3] Dunn and Swierczek, "Planned Organizational Development", Group and Organizational Studies, 4, No. 6. 1989

[4] John M. Nicholas". The Comparative Impact of Organizational Development: Interventions on Hard Criteria". Academy of Management Review, 7, No. 4. Oct. 84), 531-541

[5] R.A. Katzell and Guzzo, "Physiological Approach to Productivity Improvement".
American Psychologist. (Ap. 1993), pp. 468-472

[6] Barry A. Macy, "An Assessment of USA's Improvement and Productivity efforts". National Academy of Management, Chicago- Aug. 1986

[7] R. A. Guzzo, R. D. Jette, and R. A. Katzell, "The effect of Psychologically based intervention programmes on women productivity. A meta-Analysis", Personnel, Psychology, 38 (1985) pp. 275291.

[8] G.A. Neuman, J.E. Edwards, and N.S. Raju, "Organisational Development Intervention". A Meta-Analysis of their effects on satisfaction and other attitudes". Personnel psychology, 421 (1989) pp. 461-489.

[9] P.E. Spector, "Perceived Control by Employees" Human Relations, 39 No. 11 (1996) pp. 1005-1016.

[10] W. Pasmore, C. Francis, J. Haldeman, and A. Shani "Sociotechnical Systems, Human Relations, 35. 1982.

[11]T. Marshall Egan, "Organization development: An examination of definitions and dependent variables", Organization Development Journal; Summer 2002; 20,2 